\title{
牛大腿部海綿骨の微構造モデルによる弾性的性質評価
}

\section{Evaluation of Elastic Properties of Femoral Spongy Bone using Microstructural Model}

\author{
○学 佐野 雄哉（静岡大院） 正 坂井田 喜久（静岡大工） \\ 正 吉田 始（静岡大工）
}

Yuya Sano, Yoshihisa Sakaida,Hajime Yoshida, Shizuoka University,3-5-1 Jyohoku, Hamamatu 432-8561, Japan

Key Words: Femoral Spongy Bone, Microstructure, Elasticity, Finite Element Method

\section{1. 緒言}

若年スポーツ選手の脊椎分離症は, 腰椎の関節突起間部で の発症例が多く, 運動時に腰椎に発生する応力解析による原 因解明が望まれている。一方, 腰椎の応力解析には骨構造と 弾性的性質の把握が不可欠であるが, 人骨の弾性的性質に関 する研究例は存在するが, 骨構造との関係は不明で, 直接活 用することはできない，そこで，本研究では，骨の弾性的性 質と骨構造の関係を把握するため, 牛大腿部海綿骨の弹性的 性質と骨構造を実測するとともに，骨構造の微構造モデルを 作成し, 有限要素法と均質化法を用いて, 海綿骨梁と骨䯣の 弾性率を算出し, 弾性的性質の評洒を行った。

\section{2. 実験及び解析方法}

\section{1 供試材および試験片}

供試材は図 1 亿示寸牛大腿骨で，2つの骨頭 (No.1,2) 内 部の海綿骨から 1 辺 $10 \mathrm{~mm}$ の立方体試験片を切出した。なお， 試験片には図 2 に示寸ように大腿骨の骨軸方向が $z$ 軸となる ような直交座標系 $x y z$ を定義した。

\section{2 微構造モデルの作成}

立方体試験片は, 圧縮試験により, 弾性的性質を実測した 後, 超音波洗浄により骨髄を取除き, 再び圧縮試験により弾 性的性質を実測した.ついで, マイクロスコープ(SKM-3000A, 斎藤光学）を用いて， $z$ 軸を法線方向とする断面を $0.2 \mathrm{~mm}$ 間 隔で逐次研磨除去しながら, 図3 のような断面組織写真を合 計 50 枚撮影した. さらに, 画像処理ソフト(Tri/3D-Bon, RATOC)により断層組織画像を補間し，骨梁と骨髓からなる 海綿骨と,海綿骨梁のみの2 種類の微構造モデルを作成した. なお，モデルは 8 節点六面体要素で要素分割した．表 1 は， 骨梁と骨髄の要素数と節点数を示寸.

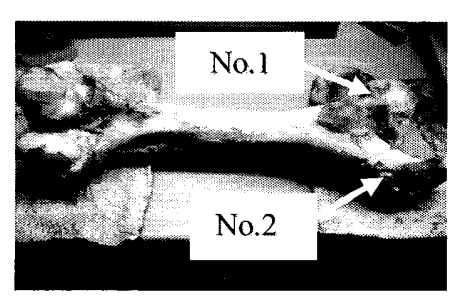

Fig. 1 Cattle thighbone

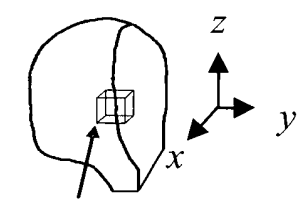

Cancellous bone

Fig.2 Definition of coordinate system.

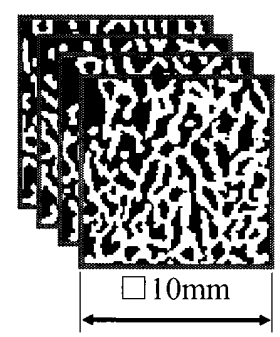

(a) Microstructure image.

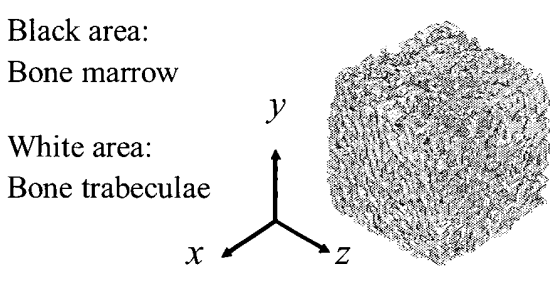

(b) 3D-model.

Fig. 3 Finite element model of cattle cancellous bone.

\section{3 均質化法による骨梁及び骨髄要素の弾性率算出}

骨梁のみの要素モデルに仮のヤング率とポアソン比を与 え, 均質化法 (VOXLCON-HG, くいんと) により, 骨梁構造 の等価弾性率を計算し, 骨梁構造の等価弾性率と実験結果が 一致するような骨梁要素のヤング率とポアソン比を求めた。 次に, 骨梁と骨髄からなる要素モデルの骨髄要素に仮のヤン グ率とポアソン比を与え, 海綿骨モデルの等価弾性率を計算 し, 実験結果と一致する骨髄要素のヤング率とポアソン比を 求めた。

\section{4 有限要素法による微構造モデルの弾性率評価}

有限要素法 (ANSYS, サイバーネット)を用い, 骨梁のみの微 構造モデルに一軸変位を加える仮想圧縮試験を行い, 実験結 果と比較した. 解析は, 荷重面の対面を負荷方向に拘束した状 態で, 荷重面上の節点に $0.1 \mathrm{~mm}$ の強制変位を与えた。

\section{3. 結果および考察}

\section{1 海綿骨の弾性的性質と微構造との関係の評価}

表 2 は圧縮試験より実測した 3 万向のヤング率を示す. 負 荷方向により, 海綿骨に弾性異方性が存在することがわかる.

図 4 は，2つの立方体試験片の微構造モデルを示す. 白色 の骨梁組織構造に注目すると, No.1の $x y$ 面, No.2の $y z$ 面は 網目状でネットワーク構造を有しているのに対し, それ以外 の面では, 図に矢印で示したように，骨梁組織が一方向にそ ろっていることがわかった。これらの特徵は断層画像を同一 方向で連続的に観察しても同様に見られた. 図 5 は骨梁部分 の面積率を求め, その平均值を横軸とし, その面に対して垂 直方向のヤング率を縦軸としたグラフを示す. group(a)はネ ットワーク構造を有する面, group (b)は骨梁軸が一方向にそ ろっている面で構成される断層構造を持つものである. 図 6 は group (a) と(b)の断層位置に対する骨梁面積率の変化を示す. 図より，骨梁の面積率とヤング率の関係は 2 つ直線 (group(a)と group(b))で表される. group(a)は group(b)に比べて, 面積率の変化がなだらかであることがわかる. すなわち, 海 綿骨の弾性的性質は骨梁の微構造と面積率に大きく依存す るといえる。

Table.1 Number of element and node for 3D-models.

\begin{tabular}{c|c|c|c|c}
\hline \multirow{2}{*}{ Specimen } & \multicolumn{2}{|c|}{ bone marrow } & \multicolumn{2}{c}{ bone trabeculae } \\
\cline { 2 - 5 } & element & node & element & node \\
\hline No.1 & 199,182 & 343,721 & 162,068 & 300,992 \\
\hline No.2 & 208,679 & 327,935 & 152,571 & 263,177 \\
\hline
\end{tabular}

Table. 2 Young's modulus of Cancellous bone.

\begin{tabular}{c|c|c|c|c}
\hline bone marrow & Specimen & $E_{x}(\mathrm{MPa})$ & $E_{y}(\mathrm{MPa})$ & $E_{z}(\mathrm{MPa})$ \\
\hline \multirow{3}{*}{ with } & No.1 & 236.8 & 309.4 & 341.4 \\
\cline { 2 - 5 } & No.2 & 333.9 & 201.8 & 189.9 \\
\hline \multirow{3}{*}{ without } & No.1 & 208.4 & 232.6 & 298.3 \\
\cline { 2 - 5 } & No.2 & 257.3 & 187.5 & 180.1 \\
\hline
\end{tabular}



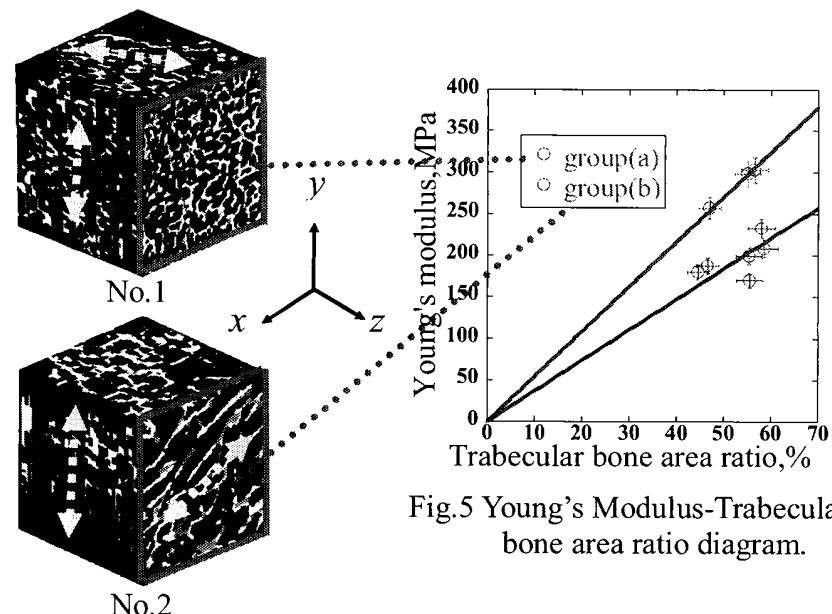

Fig. 5 Young's Modulus-Trabecular bone area ratio diagram.

Fig.4 Cubic microstructure

Models of Cancellous bone.

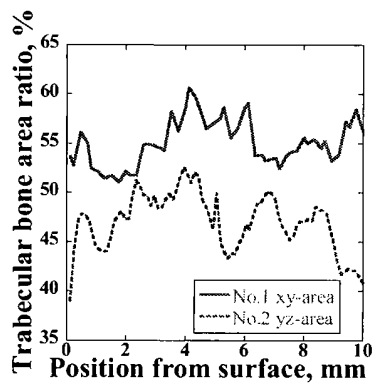

group(a)

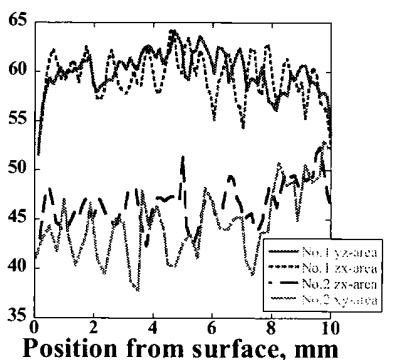

group (b)

Fig.6 Transition of trabecular bone area ratio.

Table.3 Estimated optimum Young's modulus and Poission's ratio of spongy bone using HGM.

\begin{tabular}{c|c|c|c|c}
\hline \multirow{2}{*}{ Specimen } & \multicolumn{2}{|c|}{ Bone Trabeculae } & \multicolumn{2}{c}{ Bone Marrow } \\
\cline { 2 - 5 } & $E_{o p}(\mathrm{MPa})$ & $v_{o p}$ & $E_{o p}(\mathrm{MPa})$ & $v_{o p}$ \\
\hline No.1 & 1.50 & 0.30 & $0.40 \times 10^{-2}$ & 0.49 \\
\hline No.2 & 1.70 & 0.30 & $0.35 \times 10^{-3}$ & 0.49 \\
\hline
\end{tabular}

\section{3 均質化法による骨梁及び骨髄要素の弾性率算出}

表 3 は骨梁と骨䯣要素のヤング率とポアソン比の最適值を 示す. 本研究では, 海綿骨の $z$ 方向のヤング率の実験值と均 質化法による等価弾性率が一致するように，骨梁と骨髄要素 のヤング率とポアソン比を変化させた，なお，骨髄は非圧縮 性流体と仮定し, 構造要素として, ヤング率・ポアソン比を 与えた，骨髄のヤング率は骨梁に比べてかなり小さく，海綿 骨の弾性的性質は骨梁要素で決まるといえる。一方, No.1 と No.2 では骨髄のヤング率に 1 桁の差が生じた。これは, 骨髄構造が切り出し位置により異なることに起因すると考 えることができる，そこで，海綿骨の X 線 CT 撮影を行い， 骨髄構造について検討した。図７は撮影した CT 画像をトレ 一スし，異なる領域を色分けした結果を示す。白い部分が骨 梁, 水色の部分が骨䯣である. 図より, 図 4 の微構造モデル で骨髄と考えていた領域に, 黒色で示した密度の低い領域が 観察できた。 また case1 と case2 は異なる位置から切り出し た海綿骨の断層画像で, 黒色領域の体積分率が異なることが わかる. この領域のヤング率が非常に小さいと仮定すると， 図 4 のように骨髄を均質とした計算では, 表 3 の No.1 と No.2 の骨髄のヤング率のように, 值に大きな差が生じる可能性が ある.密度の低い領域が骨髄のヤング率に及ぼす影響につい ては今後の課題である.

最後に, 表 4 は表 3 の各要素の弾性率を用いて海綿骨の等 価弾性率を均質化法により再計算した結果を示す。骨梁と骨 髄から成る複雑な微構造に依存して, 海綿骨の等価弾性率は 強い異方性を有することがわかる。

\section{4 有限要素法による微構造モデルの弾性率評価}

表 5 は有限要素法を用いた仮想圧縮試験により算出した, 一軸変形したときのヤング率を示す. 解析結果と実験結果を 比較すると， $z$ 方向のヤング率はほぼ一致したが，実験によ る弾性異方性に比べて $E_{z} / E_{x}, E_{z} / E_{y}$ の值は小さくなった．異方 性が小さい理由としては, 実験は負荷荷重と荷重点変位から ヤング率を算出しているのに対し，有限要素法による仮想圧 縮試験は，せん断変形を含めたヤング率を求めているためで あると考えている. 今後, FEM のせん断変形量を考慮して, 実験で得られたヤング率の結果と比較する予定である.

\section{4. 結言及び参考文献 (省略)}

Table.4 Analyzed apparent Elastic modulus of spongy bone using HGM.

\begin{tabular}{c|c|c|c|c|c|c|c|c|c|c}
\hline bone marrow & Specimen & $E_{x}(\mathrm{MPa})$ & $E_{y}(\mathrm{MPa})$ & $E_{z}(\mathrm{MPa})$ & $G_{x y}(\mathrm{MPa})$ & $G_{y z}(\mathrm{MPa})$ & $G_{z x}(\mathrm{MPa})$ & $v_{x y}$ & $v_{y z}$ & $v_{z x}$ \\
\hline \multirow{3}{*}{ with } & No.1 & 266.1 & 288.7 & 342.3 & 86.9 & 110.1 & 99.6 & 0.31 & 0.32 & 0.26 \\
\cline { 2 - 11 } & No.2 & 265.1 & 217.2 & 189.6 & 87.4 & 63.5 & 68.7 & 0.20 & 0.17 & 0.23 \\
\hline \multirow{3}{*}{ without } & No.1 & 208.7 & 230.6 & 299.2 & 77.7 & 101.5 & 91.2 & 0.24 & 0.24 & 0.17 \\
\cline { 2 - 10 } & No.2 & 258.1 & 194.6 & 179.6 & 85.3 & 62.0 & 67.7 & 0.17 & 0.15 & 0.21 \\
\hline
\end{tabular}

Table. 5 Young's modulus of spongy bone using FEM.

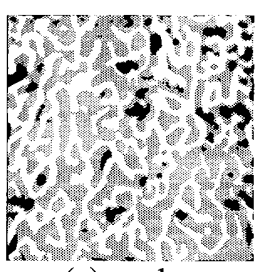

(a)case 1

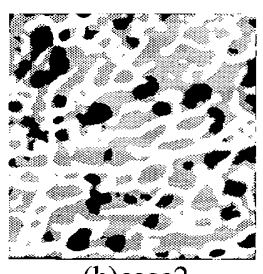

(b)case 2
Fig. 7 Traced images of spongy bones.

\begin{tabular}{c|c|c|c|c|c|c|c}
\hline bone marrow & Specimen & & $E_{x}(\mathrm{MPa})$ & $E_{y}(\mathrm{MPa})$ & $E_{z}(\mathrm{MPa})$ & $E_{z} / E_{x}$ & $E_{z} / E_{y}$ \\
\hline \multirow{4}{*}{ with } & \multirow{2}{*}{ No.1 } & Experiment & 237 & 309 & 341 & 1.442 & 1.103 \\
\cline { 3 - 8 } & & FEM & 281 & 287 & 334 & 1.189 & 1.164 \\
\cline { 2 - 8 } & \multirow{3}{*}{ No.2 } & Experiment & 334 & 202 & 190 & 0.569 & 0.941 \\
\cline { 3 - 8 } & & FEM & 275 & 258 & 197 & 0.716 & 0.764 \\
\hline \multirow{5}{*}{ without } & \multirow{2}{*}{ No.1 } & Experiment & 208 & 232 & 298 & 1.433 & 1.284 \\
\cline { 3 - 8 } & & FEM & 227 & 244 & 302 & 1.330 & 1.238 \\
\cline { 3 - 8 } & \multirow{2}{*}{ No.2 } & Experiment & 257 & 189 & 180 & 0.700 & 0.952 \\
\cline { 3 - 8 } & & FEM & 271 & 257 & 191 & 0.705 & 0.743 \\
\hline
\end{tabular}

